\title{
A further locality with foliicolous lichens in Italy, with taxonomical and ecological data on foliicolous lichens in Western Europe
}

\author{
Domenico PUNTILLO ${ }^{a}$, Olivier BRICAUD ${ }^{b}$ \& Emmanuël SÉRUSIAUX*c \\ ${ }^{a}$ Orto Botanico, Università degli Studi della Calabria, \\ 87030 Arcavacata di Rende (CS), Italy \\ ${ }^{b}$ Route des Taillades 2977, 84250 Le Thor, France \\ ${ }^{c}$ Chercheur Qualifié F.N.R.S., Département de Botanique, Sart Tilman B22, \\ B-4000 Liège, Belgique
}

(Received 20 January 2000, accepted 29 March 2000)

\begin{abstract}
- 14 lichen species and 3 lichenicolous fungi growing on them have been found on living leaves, mainly of Buxus, in a deep and sheltered ravine in Campania (Italy), at low elevation, in the Mediterranean region. These figures are similar to those at the richest sites with foliicolous lichens in the Western Pyrenees. Further data on the ecology of foliicolous lichens in Western Europe are provided. Four 'ecological' groups are recognized amongst lichens observed on living leaves in Western Europe, the strictly foliicolous one being only a minority, with either pantropical species or species with a restricted distribution. The new combination Strigula minor (Vězda) Cl. Roux \& Sérus. is introduced. (C) 2000 Adac / Éditions scientifiques et médicales Elsevier SAS
\end{abstract}

foliicolous lichens / Western Europe / Campania / Italy / Strigula / ecological groups / chorology

Résumé - 14 espèces de lichens et 3 champignons lichénicoles qui leur sont associés ont été trouvés sur des feuilles vivantes, essentiellement de Buxus, dans un ravin, profond et bien abrité, de Campanie (Italie), à basse altitude et en région méditerranéenne. Une telle diversité est proche de celle des sites les plus riches des Pyrénées Occidentales. D'autres données sur l'écologie des lichens foliicoles en Europe Occidentale sont présentées. Quatre groupes «écologiques » sont reconnus au sein des lichens observés sur les feuilles vivantes en Europe Occidentale, le groupe des espèces strictement foliicoles ne concernant qu'une minorité avec des espèces à distribution pantropicale, ou très limitée. La nouvelle combinaison Strigula minor (Vězda) Cl. Roux \& Sérus. est introduite. (C) 2000 Adac / Éditions scientifiques et médicales Elsevier SAS

lichens foliicoles / Europe occidentale / Campania / Italie / Strigula / groupes écologiques / chorologie

\section{INTRODUCTION}

Foliicolous lichens are now known from a few scattered localities throughout the Italian peninsula: Modenesi \& Serrato (1984) reported the occurrence of Byssoloma

* Correspondence and reprints: E.Serusiaux@ulg.ac.be 
leucoblepharum on Buxus leaves in Liguria; Puntillo \& Ottonello (1997) described a site in Tuscany with six species (including one foliicolous fungus) growing on leaves of Buxus and Phillyrea; and finally Puntillo (1996) reported the occurrence of twelve species in Calabria, mainly on Ruscus cladodes and Abies needles. It is thus interesting to report upon the discovery of a further locality with lichens belonging to that ecological group. Indeed it is by far the richest one in Italy, coming close to the best sites of the Western Pyrenees in France.

At this stage in our studies on foliicolous lichens in Western Europe, it is appropriate to publish a survey of the data we have gathered throughout the years on their taxonomy and ecology. There is however no doubt that this is only a preliminary review, as the discovery of the site reported here clearly demonstrates that much more remains to be found and studied. It is indeed remarkable that such a rich foliicolous flora occurs at low elevation in the Mediterranean region.

\section{THE NEW SITE IN CAMPANIA}

The site is located at $150 \mathrm{~m}$ elev., in the valley of the Bussento river at Cilento, Salerno, in the administrative region of Campania. Geological and climatic data as well as a description of the vegetation of this valley are provided by Agostini (1955). Rocks are made of Cretaceous limestone, and the climate is typically Mediterranean: rainfall is ca. $1700 \mathrm{~mm}$ per year, with a minimum in August $(29 \mathrm{~mm})$ and a maximum in December $(278 \mathrm{~mm})$. The mean annual temperature is $13.2^{\circ} \mathrm{C}$ with a minimum in January $\left(4.4^{\circ} \mathrm{C}\right)$ and a maximum in August $\left(22.5^{\circ} \mathrm{C}\right)$. Following Rivas-Martínez (1981), the site is located at the limit between the thermo- and meso-Mediterranean belts; because of its high rainfall level, it belongs to the 'perhumid ombroclimate', which is quite remarkable for the Mediterranean region. Such a situation does not occur in the Mediterranean region of southern France where the most humid localities belong to the 'humid ombroclimate' as their rainfall is less than $1300 \mathrm{~mm}$ per year. The climate of our station therefore is rather close to that of southwest France ('planitiaire thermoatlantique' belt following Géhu et al. 1984, which can be differentiated only by the absence of a dry summer period).

The valley is mainly covered by a rather dry and open forest of Quercus ilex, and the foliicolous lichens are found in a small but rather deep gorge at its bottom which is covered by a closed forest with a dense understory. The following species of trees and shrubs do occur in the gorge: Acer campestre, Alnus cordata, A. glutinosa, Carpinus orientalis, Corylus avellana, Fraxinus excelsior, F. ornus, Laurus nobilis, Ostrya carpinifolia, Quercus cerris, Q. robur and Viburnum tinus (Figs 1 and 2). Ruscus aculeatus and Buxus sempervirens are abundant in the understory. Trees and bushes on both sides of the 'canyon' are covered with luxuriant bryophytes, mainly Cryphaea heteromalla, Frullania dilatata, Metzgeria furcata, Neckera complanata, N. pennata, Radula complanata and Ulota crispa. The epiphytic lichen flora includes (lichen nomenclature following Purvis et al., 1992 throughout the paper): Arthonia cinnabarina, A. elegans, Celothelium ischnobelum (Nyl.) Aguirre, Collema furfuraceum, Degelia plumbea, Dimerella pineti, Enterographa crassa, Graphis scripta, Lobaria pulmonaria, L. virens, Nephroma laevigatum, Normandina pulchella, Opegrapha rufescens, Parmelia perlata, Pyrenula laevigata, Thelotrema lepadinum, Usnea hirta and $U$. rubicunda. Many of these species are characteristic of suboceanic conditions and are quite rare at low elevation in the Mediterranean region; they were probably much more widespread in the past, but, because of ancient and almost complete clearing of original forests, they are now restricted to a few, suitable localities. 


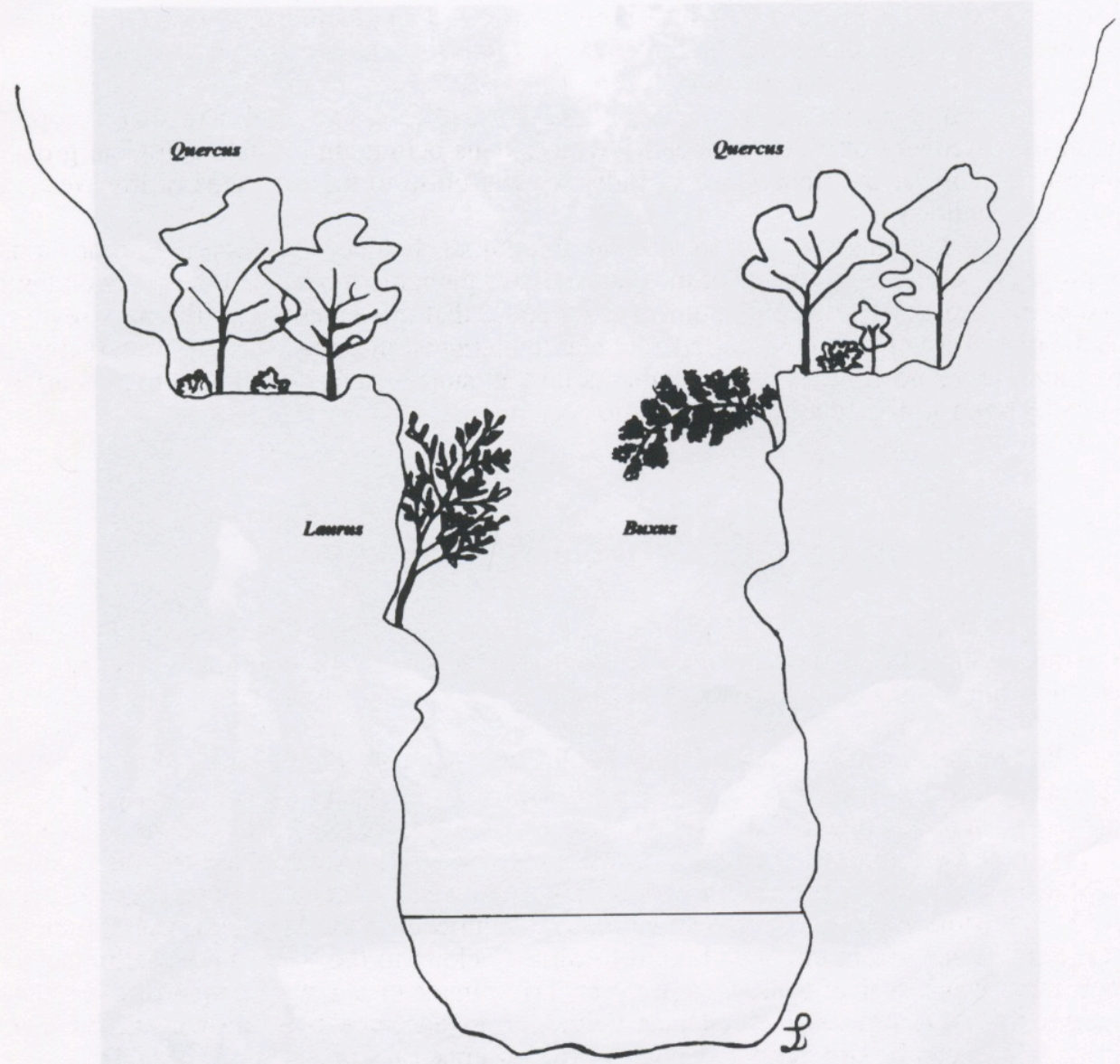

Fig. 1. Section through the Bussento canyon (Campania/Italy) where foliicolous lichens were found.

Two species are worth further comments. Enterographa elaborata (Lyell ex Leight.) Coppins \& P. James, a Western European species almost entirely restricted to Atlantic localities, has here been found on Buxus twigs and clearly shows the phytogeographical affinities of this locality; this species is new for Italy. It is also present in southeast France (Alpes-Maritimes), in deep and very humid gorges at low elevations where it is a characteristic species of the Pyrenuletum chlorospilae Giralt sub-association Enterographetum elaboratae Bricaud (Bricaud, 1996: 40-43).

A further interesting species is a puzzling Pyrenula, which could be new for science and will be dealt with elsewhere: it has 'occidentalis' ascospores (terminal lumina directly against the exospore) and rather flat perithecia with a laterally spreading involucrellum. It is close to an apparently undescribed species from SW France, which will also be studied in a forthcoming paper.

The foliicolous lichens are confined to leaves of Buxus sempervirens, Hedera helix and Laurus nobilis and cladodes of Ruscus aculeatus, and only to the individuals of those phorophytes growing on the sides of the 'canyon' (Fig. 1). Here the air is almost permanently water-saturated (in part because of a nearby waterfall and the water-fog it 


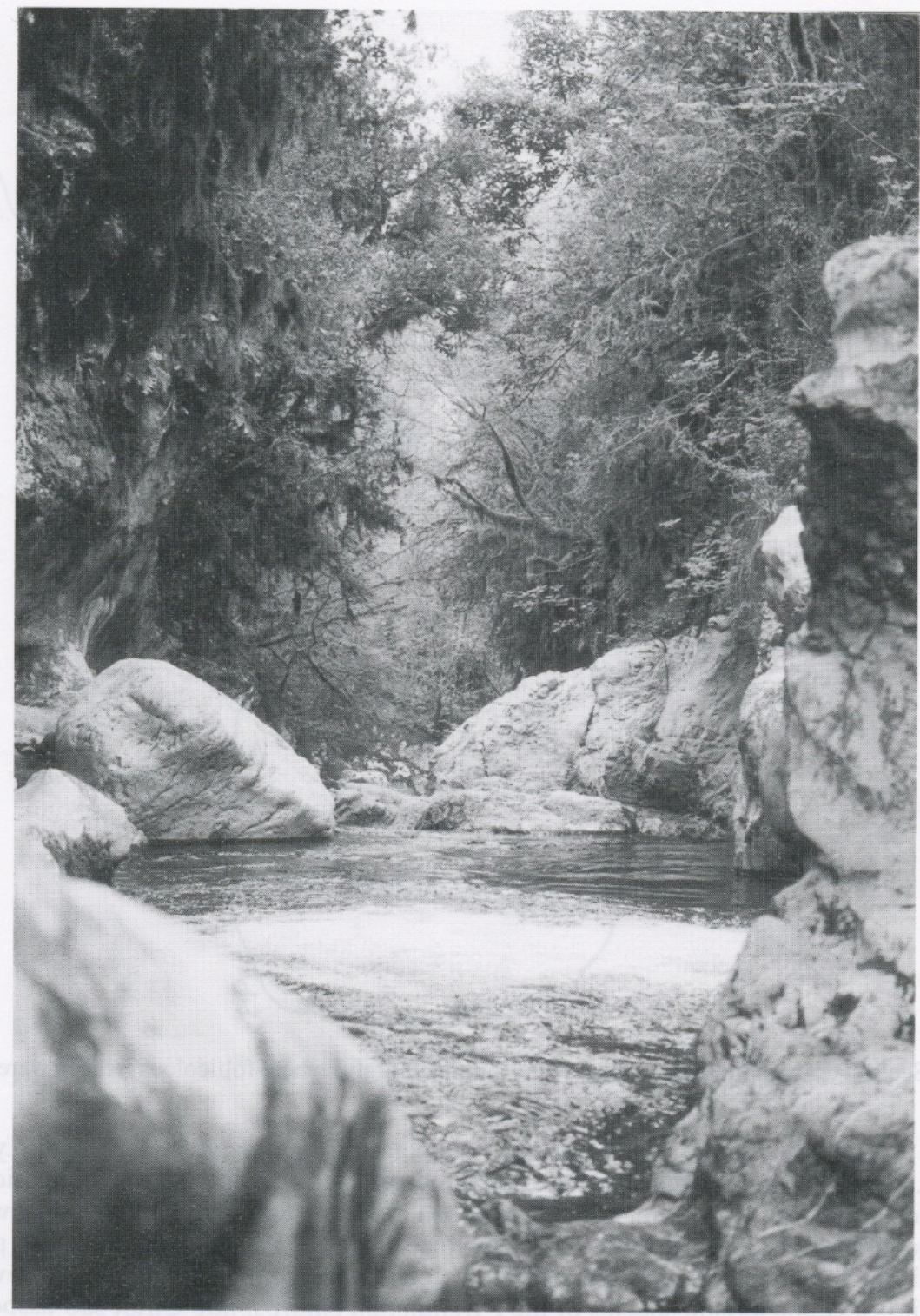

Fig. 2. View of the Bussento site (Campania/Italy) where foliicolous lichens were found.

creates), even during the dry summer, and the temperature remains rather high and uniform; moreover, the evergreen canopy provides a stable shelter to the niches occupied by the foliicolous lichens.

The following species have been found (species marked with * are new to Italy and the Mediterranean region): 
- * Ampullifera foliicola Deighton, a lichenicolous hyphomycete, also found in southern France (Gard), always confined to thalli of Byssoloma subdiscordans in Western Europe and Macaronesia

- * Bacidia colchica Vězda, a very rare species known from the Western Caucasus and two localities in the Western Pyrenees in France (Vězda, 1983; Sérusiaux, 1989)

- * Bapalmuia kakouettae Sérus., a very rare species so far only known from two very close localities in the Western Pyrenees in France but widespread and rather common in Macaronesia (Sérusiaux, 1993; Kalb et al., 2000)

- Byssoloma leucoblepharum (Nyl.) Vain.

- B. subdiscordans (Nyl.) P. James

- Fellhanera bouteillei (Desm.) Vězda

- Fellhaneropsis myrtillicola (Erichs.) Sérus. \& Coppins

- * Gyalectidium caucasicum (Elenkin \& Woronichin) Vězda, a pantropical species known in Western Europe and the Western Caucasus

- * G. setiferum Vẽzda \& Sérus., a species only known from Western Europe and the Western Caucasus (Sérusiaux 1993)

- * Gyalidea phyllophila Vẽzda, also known from the Western Pyrenees in France (Etayo \& Vězda, 1994)

- * Hansfordiellopsis lichenicola (Batista \& Maia) Deighton, a lichenicolous hyphomycete, here confined to thalli of Gyalectidium caucasicum

- Neocoleroa lichenicola (Hansf.) M. E. Barr subsp. bouteillei (Bricaud, Sérus. \& Cl. Roux) M. E. Barr [=Wentiomyces lichenicola (Hansf.) D. Hawksw. subsp. bouteillei Bricaud, Sérus. \& Cl. Roux], a lichenicolous ascomycete confined to thalli of Fellhanera bouteillei

- Porina hoehneliana (Jaap) R. Sant.

- P. oxneri R. Sant.

- * Strigula minor (Vẽzda) Cl. Roux \& Sérus. ${ }^{1}$, also known from southern France (Bricaud, 1996: 187-192)

- * S. smaragdula Fr., also known from southern France (Bricaud, 1996: 187-192)

- Woessia vasakii (Vẽzda) Sérus.

\section{FOLIICOLOUS LICHENS IN WESTERN EUROPE: SURVEY OF THE 'REMAINING' TAXONOMICAL PROBLEMS}

Although several taxonomical studies have recently appeared on foliicolous lichens in Western Europe and Macaronesia (e.g. Sérusiaux, 1993, 1996, 1998), several important taxonomical problems remain. They are briefly summarized below.

- New and luxuriant collections of Byssoloma aptrootii Sérus. in the Canary Islands indicate a close relationship with Bapalmuia kakouettae Sérus.; as a matter of fact, $B$. aptrootii represents a 'neotenic' form of the latter and is reduced into synonymy with it. Moreover, B. kakouettae is excluded from Bapalmuia but its generic position remains unclear (Kalb et al., 2000).

\footnotetext{
${ }^{1}$ C. Roux and the last author (E.Sérusiaux), with the help of O. Bricaud, have started a taxonomical revision of all species of Strigula occuring in Western Europe. The circumscription of the genus by Harris $(1975,1995)$ is accepted and it is thus necessary to transfer the epithet minor into it: Strigula minor (Vẽzda) Cl. Roux \& Sérus. comb. nov., bas.: Raciborskiella minor Vězda, Folia Geobotanica Phytotaxonomica 18: 49, 1983.
} 
- On a global scale, populations referred to Byssoloma leucoblepharum (Nyl.) Vain. are quite diverse and the species may be heterogeneous; in Europe, the status of the populations with a $\mathrm{P}+$ red apothecial margin is still to be determined.

- Several specimens of Fellhanera christiansenii Sérus. \& Vězda, a widespread foliicolous lichen in Macaronesia and also reported from Calabria/Italy, produce 5-septate ascospores and have a slightly different apothecial colour; they may represent a distinct taxon, but the matter has not yet been carefully studied.

- In Cataluña/Spain, a puzzling and most probably undescribed species of Fellhanera is found on Buxus leaves; it may be identical with the populations identified as Bacidia buxi by Vĕzda (1983) in the Western Caucasus. These obviously do not belong to that species (the type specimen of Bacidia buxi, described from southwest France, being identical with Fellhaneropsis myrtillicola; see Sérusiaux, 1996).

- The identity of the material referred to as Gyalectidium caucasicum (Elenkin \& Woronichin) Vẽzda in Western Europe is currently being examined by L. Ferraro, R. Lücking and E. Sérusiaux, and it may turn out that a different species is involved.

- Porina leptosperma Müll. Arg. and P. rubentior (Stirt.) R. Sant. belong to a pantropical, difficult species-aggregate which is currently being studied by R. Lücking.

- Foliicolous species of Strigula in Western Europe and Macaronesia are more diverse than expected, e.g. the populations from Europe (Western Caucasus and Western Europe) and Macaronesia referred to the pantropical $S$. smaragdula Fr. [=S. elegans (Fée) Müll. Arg.] may belong to a different taxon, for which the name $S$. buxi Chodat is available. The matter is currently being studied by $\mathrm{Cl}$. Roux \& E. Sérusiaux.

- Finally, the taxonomic status of foliicolous Woessia [= Bacidina] with tiny pale orange apothecia and a smooth (=not coralloid, nor sorediate) thallus in the Caucasus, Western Europe and Macaronesia remains to be studied. Vězda (1983) has referred the foliicolous populations of the Caucasus to the supposedly pantropical $W$. apiahica but the genuine identity of this species, described from Brazil, is still to be established. Specimens from Western Europe, whatever the substrate on which they grow (living leaves, twigs, rocks or any artificial substrates), seem to belong to a single species for which the epithet chloroticula is here adopted.

\section{ECOLOGICAL DATA ON WESTERN EUROPEAN FOLIICOLOUS LICHENS}

When Santesson (1952) published his outstanding world-wide monograph on foliicolous lichens, this ecological group was a mere curiosity in Western Europe and almost so in Macaronesia. Exploration of supposedly suitable habitats in these regions yielded a rather impressive and quite unexpected list of species growing on living leaves and apparently restricted to this habitat (Sérusiaux, 1989, 1993). A site with several species growing on living leaves of Buxus in a sheltered forest ravine was even found in southern Belgium (van den Boom \& Sérusiaux, 1996).

The unexpected discovery of a very rich site with such species in Campania/Italy, in a landscape which is typically Mediterranean when examined on a large scale, provides the opportunity to publish a summary of their ecology in Western Europe, even though several taxonomical problems remain (see above) and may alter the data presented here. As a matter of fact, it is now quite clear that many of these species are not 'true foliicolous' species (= species entirely and always restricted to this habitat throughout their range) but species with a wider ecological spectrum which find, on living leaves, a suitable niche. The following account is mostly based on our own observations. 


\section{Ecological characteristics of the niches occupied by foliicolous lichens in Western Europe}

By definition, foliicolous lichens occur on living leaves of trees, shrubs, lianas, ferns, etc. The climate in Western Europe is seasonal and there is usually a period of the year which is either too cold (temperate areas) or too dry (Mediterranean areas) for any significant growth of the phanerogamic vegetation. Leaves disappear during the cold periods, except for the so-called 'sempervirent' species. It is well-known that most lichen species require a rather long period of time to be established on any substrate; several species of foliicolous lichens are one of the few exceptions, as they are able to develop reproducing thalli on living leaves within a few months. The time-period is, however, too short for developing sustainable populations on deciduous leaves; foliicolous lichens must therefore find leaves which do not disappear before winter. Of course, none of the 'sempervirent' leaves is a long-lived substrate, as barks and rocks are: according to Bricaud (1996), Buxus leaves do not live more than four years in southern France. Foliicolous lichens thus form thalli which produce ascomata or asexual or vegetative means of dispersal very early.

However, foliicolous lichens are no ephemeral species ('fugitive species' in the concept of During, 1992: 17, or 'Kurzlebige' in the concept of Frey \& Hensen, 1995: 199; see Poelt \& Vězda, 1990 for a survey of ephemeral lichens). Indeed, foliicolous lichens can live as long as the leaves on which they can grow; they disappear because the leaves do. During (1992) has defined the concept of 'shuttle' species as those that are 'adapted to microhabitats that disappear predictably at varying rates but reappear frequently in the same community; this concept perfectly applies to foliicolous lichens: the living leaves on which they grow disappear, but the same substrate constantly reappears at the same topographical location and with the same ecological niches (moisture and light) ${ }^{2}$.

Foliicolous lichens have quite strict water requirements, although the leaves on which they grow have almost no capacity of retaining it. Obviously, most of the species need a stable environment, with a fairly constantly high atmospheric humidity and without any sharp microclimatic contrast: such conditions are most easily found in ravines and sheltered valleys where rivers, waterfalls or springs and the local relief can guarantee them. Basically in Western Europe, foliicolous lichens require the smooth surface provided by living leaves - which exclude most other lichen species, especially macro-lichens - and a humid and shaded habitat.

They are mostly found under suboceanic climates, and the best examples are the deep gorges in the calcareous montane ranges on both sides of the Western Pyrenees, where all Western European foliicolous species can be found (Tab. 1), except for Byssoloma diederichii (which may have been overlooked because of its very minute size; Sérusiaux, 1998). Mediterranean regions can also provide such conditions, as demonstrated by the locality reported in this paper: its list of species is very impressive, and comes close to what can be found in the Western Pyrenees.

\footnotetext{
2 During (1992: 17-20) and Frey \& Hensen (1995: 201-202) make a distinction between the so-called 'Wenigjährige Pendler (Short lived shuttle species)' and 'Besiedler (Colonists)', the former applying only to bryophytes. For bryophytes, the main difference between the two categories seems to be the size of the spores produced as well as their quantity (During, 1992: 22, Table 1.4). The distinction seems to be impossible for the foliicolous lichens dealt with here, as they all have small ascospores (except for species like Gyalectidium caucasicum, but this species very rarely produces ascomata in Western Europe). It is, however, remarkable that some characteristics given for the 'Besiedler (Colonists)' species are appropriate for several foliicolous lichens, like the representatives of the Pilocarpaceae (Byssoloma and Fellhanera): their thallus is mainly made of small granules that disperse abundantly at the early stages of colonization, through mechanical factors like rain water or small animals.
} 
Tab. 1. Foliicolous lichen species in Western Europe and Caucasus (Russia and Georgia; following Etayo \& Vězda, 1994; Sérusiaux, 1989, 1993, 1998 and Vězda, 1983)

\begin{tabular}{|c|c|c|}
\hline & W Europe & Caucasus \\
\hline \multicolumn{3}{|l|}{ Strigulaceae } \\
\hline Strigula angustata Sérus. \& Cl. Roux ad. int. & $x$ & - \\
\hline S. minor (Vězda) Cl. Roux \& Sérus. & $x$ & $\mathrm{x}$ \\
\hline S. nitidula Mont. & $\mathrm{x}$ & $x$ \\
\hline S. smaragdula Fr. & $\mathrm{x}$ & $\mathrm{x}$ \\
\hline \multicolumn{3}{|l|}{ Trichotheliaceae } \\
\hline Porina colchica Vězda & - & $\mathrm{x}$ \\
\hline P. hoehneliana (Jaap) R. Sant. & $\mathrm{x}$ & $x$ \\
\hline P. leptosperma Müll. Arg. & $\mathrm{x}$ & - \\
\hline P. oxneri R. Sant. & $\mathrm{x}$ & $\mathrm{x}$ \\
\hline P. rubentior (Stirt.) R. Sant. & $\mathrm{x}$ & $\mathrm{x}$ \\
\hline \multicolumn{3}{|l|}{ Asterothyriaceae } \\
\hline Gyalidea phyllophila Vězda & $\mathrm{x}$ & $\mathrm{x}$ \\
\hline \multicolumn{3}{|l|}{ Gomphillaceae } \\
\hline Echinoplaca epiphylla Fée & - & $\mathrm{x}$ \\
\hline Gyalectidium caucasicum (Elenk. \& Woron.) Vězda & $\mathrm{x}$ & $\mathrm{x}$ \\
\hline G. colchicum Vězda & - & $\mathrm{x}$ \\
\hline G. setiferum Vẽzda \& Sérus. & $\mathrm{x}$ & $\mathrm{x}$ \\
\hline \multicolumn{3}{|l|}{ Bacidiaceae s. 1 . } \\
\hline Bacidia colchica Vẽzda & $\mathrm{x}$ & $\mathrm{x}$ \\
\hline Scoliciosporum curvatum Sérus. & $\mathrm{x}$ & - \\
\hline Woessia apiahica (Müll. Arg.) Sérus. & - & $\mathrm{x}$ \\
\hline W. chloroticula (Nyl.) comb. ined. & $\mathrm{x}$ & - \\
\hline W. vasakii (Vẽzda) Sérus. & $\mathrm{x}$ & $\mathrm{x}$ \\
\hline \multicolumn{3}{|l|}{ Pilocarpaceae } \\
\hline Byssoloma diederichii Sérus. & $\mathrm{x}$ & - \\
\hline B. leucoblepharum (Nyl.) Vainio & $\mathrm{x}$ & $\mathrm{x}$ \\
\hline B. subdiscordans (Nyl.) P. James & $\mathrm{x}$ & $x$ \\
\hline Bapalmuia kakouettae Sérus. & $\mathrm{x}$ & - \\
\hline Fellhanera bouteillei (Desm.) Vězda & $\mathrm{x}$ & $\mathrm{x}$ \\
\hline F. christiansenii Sérus. \& Vězda & $\mathrm{x}$ & - \\
\hline Bacidia buxi auct., non Vězda \& Vivant & $x ?$ & $\mathrm{x}$ \\
\hline Fellhaneropsis myrtillicola (Erichs.) Sérus. \& Coppins & $\mathrm{x}$ & - \\
\hline \multicolumn{3}{|l|}{ Ectolechiaceae } \\
\hline \multicolumn{3}{|l|}{ Vězdaeaceae } \\
\hline Vẽzdaea dawsoniae Döbb. & $\mathrm{x}$ & $\mathrm{x}$ \\
\hline \multicolumn{3}{|l|}{ Arthoniaceae } \\
\hline Arthonia muscigena $\mathrm{Th}$. Fr. & $\mathrm{x}$ & $\mathrm{x}$ \\
\hline
\end{tabular}

Several species which are 'regularly' foliicolous in the laurisilva of Macaronesia are not mentioned in this table, although they do occur in Western Europe. The reason is that, in Western Europe, they have never or very rarely been found on living leaves. This group includes Byssoloma croceum Sérus. \& Puntillo, B. marginatum (Arnold) Sérus. and Fellhaneropsis vezdae (Coppins \& P. James) Sérus. \& Coppins. 
A shorter list of foliicolous species may also occur in less suitable conditions, e.g. where the microclimate is more contrasted (dry during summer in the Mediterranean region, or quite cold during winter elsewhere, including in montane areas). All such localities, however, enjoy rather long periods of dense fog or mist - which compensate the low level of precipitations - usually during winter and spring, and are protected from wind disturbance and sun exposure. They nevertheless go through dry periods: one of us (O. Bricaud) has measured atmospheric humidity as low as $60 \%$ during summer for sites with Porina rubentior, P. leptosperma and Strigula smaragdula in the Drevenne gorges (Vercors/France) and between 48 and $52 \%$ in spring for sites with Porina hoehneliana and Strigula smaragdula in southern France (Gard).

The availability of 'sempervirent' leaves is the first limiting factor for the distribution of foliicolous lichens in Western Europe. This is clearly demonstrated by Strigula nitidula and S. smaragdula, which are both found on introduced Buxus well outside the natural range of this phorophyte (the former in Brittany/France and the latter on the south side of Lac Léman/France), and even by the very rare Gyalectidium setiferum which is known from Brittany/France, well away from its strongholds in the Pyrenees, on needles of Abies, which is an introduced species there. The dispersal capacity of these species is thus quite remarkable (although, but this hypothesis seems unlikely to us, one could argue they were transported in their new localities with their phorophyte). Within the sites where they occur on native species, foliicolous species are also able to colonize the leaves of introduced species, especially in southwest France, where exotic weeds are widespread along rivers. For example, at the type-locality of Bacidia buxi in southwest France (see Sérusiaux, 1996 for more details), foliicolous lichens are abundant on bushes of the native Buxus, but also colonize nearby leaves of introduced Diospyros and Elaeagnus (two alien shrubs in that valley).

Foliicolous lichens are not very demanding as far as the nature of the substrate on which they grow is concerned: in tropical forests, many 'strictly foliicolous' species can be found growing and fruiting exuberantly on plastics (Sipman, 1994; Lücking, 1998c; E. Sérusiaux, pers. obs.). We strongly suspect that European foliicolous lichens would not behave differently, and experiments with artificial 'slippery' surfaces disposed in suitable localities should be organized. So far, in Europe, a single species of foliicolous lichens has been found on plastic bags in southern France (Vaucluse): Porina oxneri, together with Woessia chloroticula and Opegrapha vermicellifera.

Anyway, the very best phorophyte for foliicolous lichens in Western Europe is Buxus sempervirens, which hosts all the species hitherto detected (Tab. 2). This shrub has a quite enigmatic distribution in Western Europe (Meusel et al., 1978) and is almost lacking from wide areas, like northwest Spain and northern Portugal where it would provide a formidable habitat for foliicolous lichens. Other native phorophytes include leaves of Hedera helix s. 1., Ilex aquifolium, Laurus nobilis, Phillyrea media, Quercus ilex, and Viburnum tinus, stems and cladodes of Ruscus aculeatus, and needles of Abies alba and Picea abies. Their leaves are usually colonized by the most common and less demanding foliicolous species like Fellhanera bouteillei or Fellhaneropsis myrtillicola, with noteworthy exceptions: in south Italy, Porina hoehneliana can be quite abundant on Hedera leaves at ground level in the Vallone San Tommaso (Calabria), and many species, incl. Gyalectidium caucasicum (with Hansfordiellopsis lichenicola overgrowing it) and Woessia vasakii, are abundant on leaves of Laurus nobilis in the site reported in this paper when the trees are very close to the ravine.

In tropical forests, the most diverse foliicolous lichen flora is found on long-lived leaves with a grooved or finely ornamented surface and a high surface continuity (Lücking 1998b; E. Sérusiaux, pers. obs. in Papua New Guinea). Although the very detailed and fascinating studies conducted in the Braulio Carrillo National Park 
Tab. 2. General ecology of the lichen species found on living leaves in Western Europe

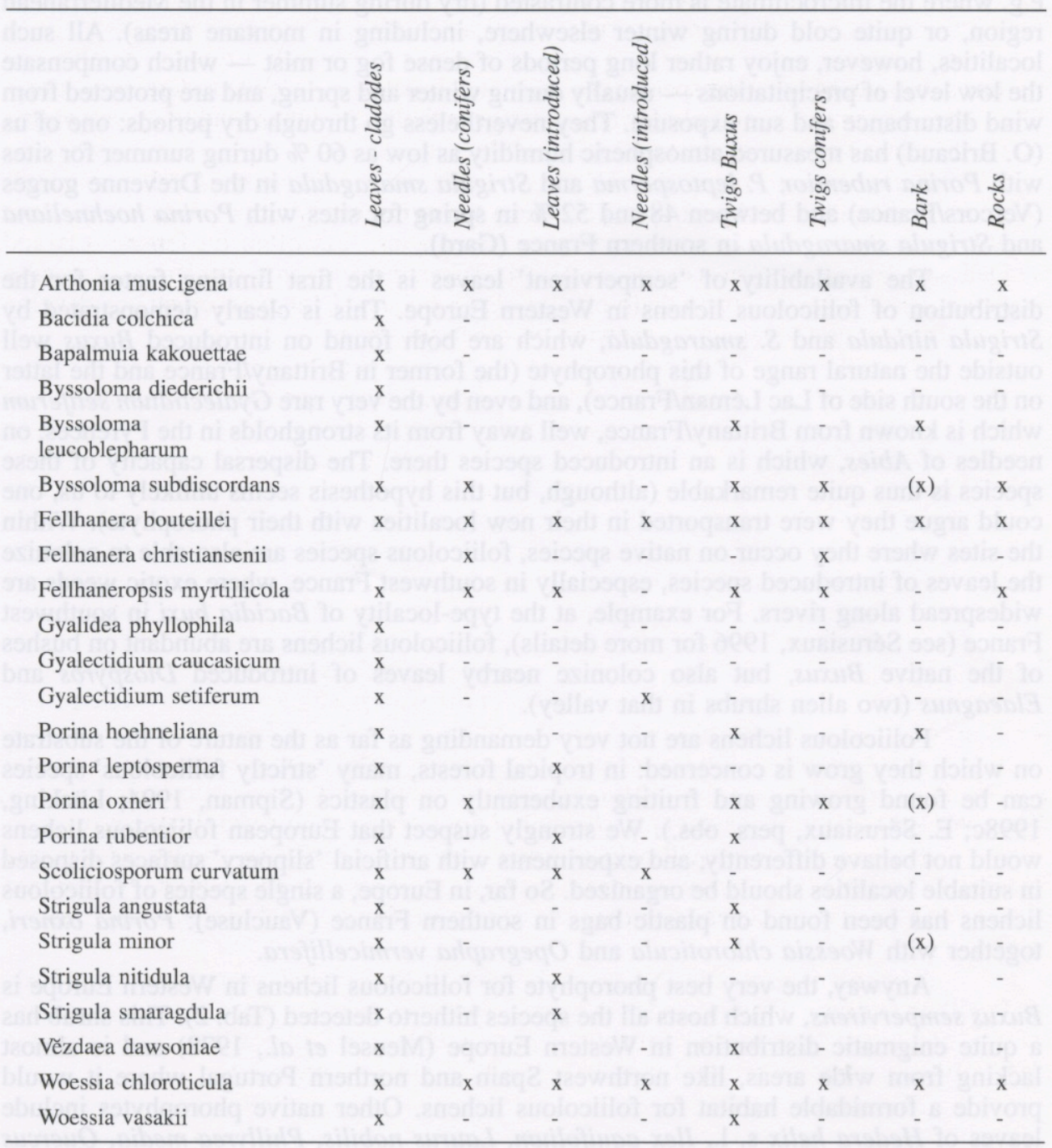

(Costa Rica) by R. Lücking (1998a \& b, 1999a \& b) have never been made in the best sites of Western Europe, we suspect that the very 'fragmented' substrate provided by the numerous, very small and smooth leaves of Buxus sempervirens or by the needles of Abies and Picea do not alter the floristic composition, nor the organization of the communities formed by foliicolous lichens.

\section{Ecological groups of 'foliicolous' lichens in Western Europe}

Four 'ecological' groups can be recognized amongst the species found on living leaves in Western Europe: 
(1) The first group includes ubiquitous species, viz. those growing on very different substrates (living leaves, twigs, bark and non-porous rocks) provided that they face little, if any, competition. The only important habitat where they have never been found is soil, most probably because they do not appreciate such a rough, unstable and porous substrate. Most of the species classified in this category tolerate ruderal conditions. They have a granular to entirely farinose-sorediose thallus and thus tend to appear at first along the main veins or against any relief on leaves.

Arthonia muscigena Th. Fr. [= A. exilis auct. brit., non (Flörke) Anzi, A. leucodontis (Poelt \& Döbb.) Coppins] is known 'on twigs, especially of Sambucus, or tree trunks (e. g. Acer, Ulmus), sometimes over bryophytes, less often on fence-posts and shaded, +/-acid rocks' (Purvis et al., 1992: 84). When growing on living leaves, it usually is a commensalistic species on thalli of Woessia $[=$ Bacidina $]$ but can sometimes develop its own thallus, as it does when growing on other substrates.

Fellhanera bouteillei can be found on all continents, except Antarctica. It is able to grow on almost any substrate, including rock crevices near the sea and plastics in tropical forests, but it is a poor competitor. In Belgium, for example, it is known from three different habitats: living leaves of Buxus in a subnatural forest in a sheltered ravine at $120 \mathrm{~m}$ elev., needles and twigs of Picea in artificial plantations at ca. $500 \mathrm{~m}$ elev., and Calluna and Vaccinium twigs at the edges of old meadows along small rivers between 350 and $450 \mathrm{~m}$ elev. In the Western Pyrenees, it is common on Buxus leaves and on Ruscus cladodes in deciduous forests, and especially in deep ravines; it is apparently not able to colonize other habitats. Indeed, the epiphytic and epilithic cryptogamic flora is there exuberant and dominated by macro-lichens: $F$. bouteillei cannot find its place amongst them, but in a few sites, it can be seen on the leached bark of old boles of Fagus, almost permanently moistened by water flow, at the very position where the diaspores of most species cannot be established. There is, however, no doubt that in Western Europe, it preferentially grows on living leaves of Buxus in sheltered places at low elevations and on Abies and Picea needles in natural or artificial forests at mid-elevations. Contrary to the other species in this category, $F$. bouteillei does not tolerate ruderal conditions.

Fellhaneropsis myrtillicola is known on acids rocks in shaded and humid localities, on Vaccinium twigs in dense thickets, on Abies and Picea twigs in montane forests and on living leaves of Buxus, especially in Europe S of Belgium (Sérusiaux, 1996).

Woessia chloroticula (Nyl.) comb. ined. [= Bacidina chloroticula (Nyl.) Vẽzda $\&$ Poelt] grows on « various shaded substrata, such as tree bases and exposed roots, tops of cut stumps and fence posts, cement and brick rubble, and tarmacadam » (Purvis et al., 1992: 107). Its occurrence on living leaves is thus not a surprise.

Two species of Byssoloma also belong to this group, although they are not as ubiquitous as the previous species: in Western Europe, B. leucoblepharum is also found on bark, either smooth (e.g. Corylus or young Populus tremula) or much more cracked (e.g. old Quercus bark) and on twigs of Calluna in heaths; B. subdiscordans also occurs on sheltered acid rocks, on twigs of Calluna, and on twigs and needles of Abies and Picea in montane forests (Sérusiaux, 1998). The former can occur on the two substrates at the same site, especially in the Western Pyrenees (France and Spain) but such a situation is very rare elsewhere (seen once in Gard/France, corticolous and foliicolous on Quercus ilex).

Scoliciosporum curvatum Sérus. is also placed here, although it has been found only on living leaves of Buxus and on twigs and needles of Abies and Picea throughout its range in Western Europe (from southwest Norway to northern Spain; Sérusiaux, 1993). It is not very demanding as far as air humidity is concerned, and we suspect that this species is overlooked and could also grow on other substrates, including bark and rocks. 
Vẽzdaea dawsoniae Döbb. should also fall into this category, although in Western Europe (mainly southwest France), it is known only from living leaves and twigs in localities with constant high humidity. This is a very inconspicuous and perhaps ephemeral species; it is widespread in the Tropics and when carefully looked for, it can be found on almost any substrate in suitable localities (e. g. found on rocks at water level by a stream in Guadeloupe, West Indies; E. Sérusiaux, unpublished).

(2) The second group concerns species which are strictly 'foliicolous' throughout their range. These have a smooth or farinose thallus, and three of them are able to 'follow' their phorophytes in localities where they have been introduced by human activities, or to find other suitable phorophytes well beyond their natural range. It can be divided into two subgroups:

The first one includes pantropical species, viz. species which have their main range in tropical areas with extensions into mild oceanic and suboceanic areas. Gyalectidium caucasicum falls into this category. The only two Strigula species with a subcuticular thallus in the Western European flora also do, but they can colonize living leaves of phorophytes outside their natural range: $S$. nitidula is rare and local in Western Europe (most of its localities are in southwest France) but also grows on introduced Buxus in Brittany/France; $S$. smaragdula is less rare and more widespread and is also able to colonize introduced Buxus in Savony/France (south of Lac Léman/France).

The second subgroup includes rare species with a restricted distribution: Bacidia colchica (known from the Western Caucasus and Western Europe), Bapalmuia kakouettae (known from SW France, Campania/Italy and Macaronesia), Byssoloma diederichii (a most probably overlooked species, known from Western Europe and Macaronesia), Fellhanera christiansenii (abundant in Macaronesia, mainly on leaves; in Europe, restricted to Calabria/Italy where it is very rare and found only on needles and twigs of conifers), and Gyalectidium setiferum (found in the Western Caucasus and on both sides of the Pyrenees, but able to colonize Abies needles in Brittany/France, where this tree is introduced).

Gyalidea phyllophila should also fall into this group as it is known from the Western Caucasus, a single locality in SW France, and the Italian site dealt with in this paper, but it also occurs in Guinea/ West Africa (Vězda, 1973).

3) The third group includes species which are equally abundant on living leaves and on twigs, or even more frequent on twigs, which may represent their primary habitat. All but one (Woessia vasakii, see below) have a smooth thallus.

Species which grow on living leaves and twigs of Buxus are Porina hoehneliana, P. leptosperma, P. rubentior, Strigula angustata, S. minor and Woessia vasakii. The case of Porina oxneri is similar but this species can also be found on needles and twigs of Abies and Picea. S. minor is able to colonize twigs and leaves of Buxus outside the natural range of its phorophyte (for example in Savony/France, $\mathrm{S}$ of Lac Léman), and has even once been found on the bark of Alnus glutinosa in Calabria/Italy. Porina hoehneliana has also been found on leaves of Hedera and Quercus ilex, on cladodes of Ruscus and once on bark; it can develop healthy populations in meticulously clipped hedges of Buxus, as observed in a park in Navarra/Spain. P. leptosperma and P. rubentior are most common in southwest France but are also present on Ruscus cladodes and introduced Buxus in Brittany/France (Bricaud, 1996: 192).

Young twigs (less than 2 years old) and leaves of Buxus have a very similar surface (presence of a cuticule over a 'parenchyme chlorophyllien'; see Bricaud, 1996). Thus it is not surprising that most foliicolous species are also able to grow on such twigs. However, species placed in this group can enjoy older twigs for another one or two years, 
after the disapperance of the cuticule and when the lignification of the surface has begun. Detailed studies of their population dynamics seem to demonstrate that their primary habitat actually is the twigs. Indeed, their most luxuriant thalli grow on twigs, and they follow their annual growth and colonize the petioles, and eventually the leaves, from their bases.

The situation with Woessia vasakii may be somewhat different as this species has a granular-coralloid thallus, sometimes dissolving into soralia; it can be found on leaves, usually near the main nerve, and along the twigs, especially at the nodes where the thallus granules can easily accumulate. Its exuberance at the nodes could thus be more a 'mechanical' effect than an ecological preference, but can also be interpreted as the result of a more favorable ecological niche as the nodes remain moistened for longer periods than leaves and twigs.

(4) The last group includes accidental species, which occur on living leaves because they are abundant in the nearby environment and produce enough diaspores to 'saturate' it and thus being able to colonize almost any habitat (accessibility concept: see Lambinon, 1968). The colonisation dynamics of such species is also quite rapid, and demonstrates how quickly they can react to the apparition of any suitable habitat.

Many widespread and 'weedy' lichen species fall in this category and it is beyond the scope of this paper to make a complete list. The most common ones are Anisomeridium polypori (Ellis \& Everh.) M. E. Barr [= A. nyssaegenum (Ellis \& Everh.) R. C. Harris], Bacidia arceutina and Phlyctis argena. On needles of Abies and Picea, Fellhanera subtilis can be quite common; as this species is seldom found on living leaves of Buxus, its inclusion in the first group could be soundly argued.

It is however interesting to report on a few remarkable examples. In the gorges of SW France, where all but one foliicolous lichens of Western Europe occur (see above), several rather rare or overlooked species have been found on living leaves, like Opegrapha multipuncta Coppins \& P. James and Psoroglaena stigonemoides (Orange) Henssen (= Macentina stigonemoides Orange). In a small ravine in central France (Aveyron; see Foucault et al., 1982 and Sérusiaux, 1998 for more details on this locality), where foliicolous lichens are representend by 11 species plus 2 lichenicolous fungi growing on them, the conditions are so suitable for bryophytes and lichen species of the Lobarion that the branches and even the twigs and leaves of Buxus are covered with such species; on twigs and nearby leaves, the following species were collected: Leptogium lichenoides, Nephroma laevigatum, $N$. parile, Normandina pulchella, Sticta fuliginosa, $S$. limbata and several others.

The occurrence of epiphytic species on living leaves can also be explained by the presence of dust on them. This can be the case at ground level by rivers or along tracks in rather open conditions. We believe that such ruderal conditions explain the occurrence of species like Hyperphyscia adglutinata, Physcia adscendens, P. tenella, Scoliciosporum perpusillum Körber, $S$. sarothamni (Vain.) Vězda, and others on living leaves of Buxus in Western Europe. Such a phenomenon is even more conspicuous in Macaronesia, e. g. in Tenerife and Gomera in the Canary Islands, on living leaves of the Lauraceae along gravel road or tracks going the laurisilva.

Finally, nitrophilous species on living leaves of Buxus, like Physcia adscendens and Candelaria concolor, can be associated with droppings of perching birds on nearby cliffs. Such a situation has been observed in southern France.

The above delimitation of 'ecological groups' of foliicolous lichens is of course tentative and mainly provides details on their preferential substrates throughout Western Europe. Other choices could be made to organize such 'ecological groups', the other most obvious alternative being the water requirements of each species. Indeed, the species 
found on living leaves have quite different spectra of water needs, especially towards the stability of the atmospheric water content and dessiccation speed of 'their' leaves. Such a classification has not yet been established for more detailed ecological studies of sites are needed.

\section{Communities formed by foliicolous lichens in Western Europe}

As already stated above, the richest foliicolous lichen flora can be found in climatically stable and sheltered ravines, mostly on leaves and twigs of Buxus, either in the mild oceanic climate of the Western Pyrenees or in protected sites of the Mediterranean region. Such localities can have a rather long list of species, the very best one being the deep gorges of the Western Pyrenees where all species but one have been found (see above). In these sites, the 'foliicolous' species, even the most ubiquitous ones, are restricted to that habitat, except for Byssoloma leucoblepharum which also grows on bark of nearby trees or shrubs.

Outside such localities, the species list gets smaller and usually include only ubiquitous species (Arthonia muscigena, Fellhanera bouteillei, Fellhaneropsis myrtillicola and Woessia chloroticula; category 1 - Byssoloma subdiscordans being present or not) or almost so (like Scoliciosporum curvatum). These sites are characterized by a much more contrasted micro-climate, either with a dry or cool period. However they enjoy rather long periods of dense fog or mist, mainly during winter and spring, and are protected from wind disturbance and sun exposure. The community formed by these species is observed

(a) on Buxus leaves in the Mediterranean region, where B. subdiscordans is present in the best protected sites,

(b) in the temperate zone but much further North (like the locality in south Belgium), B. subdiscordans being totally absent,

(c) on needles and twigs of Abies and Picea in natural montane forests in Central Europe and the Mediterranean region, B. subdiscordans being now almost extinct, and finally

(d) on needles and twigs of Picea at lower elevations in Central Europe (from E Belgium and Luxembourg to Austria) in natural stands or artificial plantations, where $B$. subdiscordans has never been found.

(b) and (c).

Fellhanera subtilis is usually present, and sometimes abundant, in situations (a),

The dynamics of the colonization of leaves or needles in such sites is very characteristic: it occurs within a few months (always by the end of the first year of existence of the supporting leaves or needles) and is quite 'explosive', e. g. most of the available surface of leaves in the suitable conditions is covered by the foliicolous lichens. The most frequent and conspicuous species that follows such a pattern is Fellhanera bouteillei; to a certain extent, Gyalectidium caucasicum has a similar behavior in the Italian locality reported here, especially on Laurus nobilis leaves on which it forms numerous small thalli almost as soon as the young leaves appear. Such a quick and explosive colonization of the leaves strongly contrasts with the behaviour of the species that characterize the richest and more sheltered and stable sites or microniches: indeed, species like those of Strigula or Porina need more time to cover the leaves surface. The studies of colonization dynamics of foliicolous lichens in south France form a major part of the work of one of us (O. Bricaud) and will be dealt with in a forthcoming paper.

Finally, it is interesting to report the recent expansion of the foliicolous species with an 'explosive' dynamic. Indeed, several localities where some species (e.g. Fellhanera bouteillei) are common on Buxus leaves have been monitored for about 
12 years and there is no doubt that the leaves' surface covered by those species is now much larger. This may be explained by the disuse of their exploitation as coppices and a succession of rather humid summers since the early nineties.

Acknowledgements. The authors, and especially E. Sérusiaux, thank very warmly the following institutions, herbaria, colleagues and friends for placing most valuable material at their disposal: Drs A. Aptroot, F. Berger, P. van den Boom, O. Breuss, B. J. Coppins, P. Diederich, J. Etayo, A. Gomez-Bolea, K. Kalb, R. Lücking, W. Obermayer, C. Roux, H. Sipman, B, BC, BERN, BG, BM, E, G, GALW, GOET, GZU, H, JE, KOELN, LISU, M, MARSSJ, OXF, S, STU, TUR, UPS, ZT, W. They would also like to acknowledge the precious help of the following colleagues and friends for their comments and suggestions on an early draft of this manuscript: Dr P. Diederich, Prof. J. Lambinon, Dr R. Lücking \& Dr C. Roux, as well as two anonymous referees for their comments and suggestions.

\section{REFERENCES}

AGOSTINI R., 1955 - Rinvenimenti di Buxus sempervirens L. lungo le valli del torrente Peglio, del fiume Bussento e del Rio di Casaletto nell'Appennino Lucano. Delpinoa 8: 239-285.

BRICAUD O., 1996 - Les peuplements lichéniques corticoles sciaphiles et foliicoles méditerranéens de la France méridionale. Université d'Aix-Marseille III, thèse de doctorat.

DE FOUCAULT B., SÉRUSIAUX E. \& VAN HALUWYN C., 1982 - Une nouvelle station française de lichens foliicoles dans le Massif central occidental (Aveyron). Cryptogamie, Bryologie \& Lichénologie 3: 73-76.

DURING H. J., 1992 - Ecological classification of bryophytes and lichens. In: Bates J. W. \& Farmer A. M. (ed.), Bryophytes and Lichens in a Changing Environment. Clarendon Press, Oxford, pp. 1-31.

ETAYO J. \& VĔZDA A., 1994 - Two new species of Gyalidea from Europe. Lichenologist 26: 333-335.

FREY W. \& HENSEN I., 1995 - Lebensstrategien bei Pflanzen: ein Klassifizierungsvorschlag. Botanische Jahrbücher für Systematik, Pflanzengeschichte und Pflanzengeographie 117: 187-209.

GÉHU J.-M., GÉHU-FRANCK J. \& BOURNIQUE C., 1984 - Sur les étages bioclimatiques de la région eurosibérienne française. Documents Phytosociologiques 8: 29-43.

HARRIS R.C., 1975 - A taxonomic revision of the genus Arthopyrenia Massal. s. 1. (Ascomycetes) in North America. PhD Thesis, Michigan State University (USA), 263 p.

HARRIS R. C., 1995 - More Florida Lichens, including the 10c tour of the pyrenolichens. New York, privately published, $192 \mathrm{p}$.

KALB K., LÜCKING R. \& SÉRUSIAUX E., 2000 - Studies in Bacidia sensu lato (Lichenized Ascomycetes: Lecanorales) I. The genus Bapalmuia Sérus. Mycotaxon (in prep.)

LAMBINON J., 1968 - Anomalies écologiques et accessibilité: l'exemple de quelques lichens de Belgique et du Luxembourg. Nova Hedwigia 16: 403-407.

LÜCKING R., 1998a - Ecology of foliicolous lichens at the 'Botarrama' trail (Costa Rica), a neotropical rain forest site. II. Patterns of diversity and area cover, and their dependence on microclimate and phorophyte species. Ecotropica 4: 1-24.

LÜCKING R., 1998b - Ecology of foliicolous lichens at the 'Botarrama' trail (Costa Rica), a neotropical rain forest. III. Phorophyte ranges and patterns of phorophyte preferences. Phyton 38: 195-219.

LÜCKING R., 1998c - 'Plasticolous' lichens in a tropical rain forest at La Selva Biological Station, Costa Rica. Lichenologist 30: 287-301.

LÜCKING R., 1999a - Ecology of foliicolous lichens at the 'Botarrama' trail (Costa Rica), a neotropical rain forest. I. Species composition and its ecogeographical implications. Biotropica 31: 553-564.

LÜCKING R., 1999b - Ecology of foliicolous lichens at the 'Botarrama' trail (Costa Rica), a neotropical rain forest. IV. Species associations, their salient features and their dependence on environmental variables. Lichenologist 31: 269-289. 
MEUSEL H., JÄGER E., RAUSCHERT S. \& WEINERT E., 1978 - Vergleichende Chorologie der Zentraleuropäischen Flora. Gustav Fischer Verlag, Jena. Band II - Karten, 421 p. (see p. 273 for Buxus), - Text, 418 p. (see p. 274 for Buxus).

MODENESI P. \& SERRATO G., 1984 - Première station en Italie d'un lichen foliicole. Cryptogamie, Bryologie \& Lichénologie 5: 289-290.

POELT J. \& VEZDA A., 1990 - Über kurzlebige Flechten. Bibliotheca Lichenologica 38: 377-394.

PUNTILLO D., 1996 - I Licheni di Calabria. Museo Regionale di Scienze Naturali, Torino, 229 p. + plates.

PUNTILLO D. \& OTTONELLO D., 1997 - A new foliicolous lichen station in Italy. Lichenologist 29: $388-390$.

PURVIS O. W., COPPINS B. J., HAWKSWORTH D. L., JAMES P. W. \& MOORE D. M., 1992 The lichen flora of Great Britain and Ireland. Natural History Museum Publications, London, $710 \mathrm{p}$.

RIVAS-MARTÍNEZ S., 1981 - Les étages bioclimatiques de la végétation de la péninsule ibérique. Anales de Jardin Botanico de Madrid 37: 251-268.

SANTESSON R., 1952 - Foliicolous lichens I. A revision of the obligately foliicolous, lichenized fungi. Symbolae Botanicae Upsalienses 12 (1): 1-590.

SÉRUSIAUX E., 1989 - Foliicolous lichens: ecological and chorological data. Botanical Journal of the Linnean Society 100: 87-96.

SÉRUSIAUX E., 1993 - New taxa of foliicolous lichens from Western Europe and Macaronesia. Nordic Journal of Botany 13: 447-461.

SÉRUSIAUX E., 1996 - Foliicolous lichens from Madeira, with the description of a new genus and two new species and a world-wide key of foliicolous Fellhanera. Lichenologist 28: 197-227.

SÉRUSIAUX E., 1998 - Deux nouvelles espèces de Byssoloma Trev. (Lichens, Pilocarpaceae) d'Europe occidentale et de Macaronésie. Cryptogamie, Bryologie \& Lichénologie 19: 197-209.

SIPMAN H., 1994 - Foliicolous lichens on plastic tape. Lichenologist 26: 311-312.

VAN DEN BOOM P. \& SÉRUSIAUX E., 1996 - A site with foliicolous lichens in Belgium. Belgian Journal of Botany 129: 19-23.

VĔZDA A., 1973 - Foliicole Flechten aus der Republik Guinea (W-Afrika). I. Acta Musei Silesiae, ser. A, 22: 67-90.

VĔZDA A., 1983 - Foliicole Flechten aus der Kolchis (West-Transkaukasien, UdSSR). Folia Geobotanica Phytotaxonomica 18: 45-70. 